\title{
Hubungan antara Big Five Personalty dan Religiusitas dengan Subjective Well-being Karyawan
}

\author{
Sukri Karim \\ jingkigayo@gmail.com
}

\begin{abstract}
Subjective wellbeing is an individual's affective and cognitive evaluation of life perceived in the workplace. One of theories related to well-being is the big five personality and religiosity. This study aims to determine the relationship between the big five personality and religiosity with subjective well-being in employees of University of Muhammadiyah Malang. The number of subjects in this study as many as 55 employees, the method of analysis using non parametric statistical test that is spearman correlation. The results show that big five personality especially extraversion, openness and religiosity are related to subjective well-being, while agreeableness, conscientiousness and neuroticism have no relation with well-being.
\end{abstract}

Key words : big five personality, religiosity, subjective well-being.

\section{PENDAHULUAN}

Pada dasarnya setiap manusia berhak untuk merasakan kebahagiaan atau kesejahteraan tidak terkecuali bagi seorang karyawan Universitas Muhammadiyah Malang (UMM) yang bekerja setiap hari untuk menjalankan roda sebuah kampus atau tempatnya bekerja. Dengan adanya kesejahteraan dan kebahagiaan maka, karyawan akan sangat menikmati pekerjaannya, akan terjalin komunikasi, kerjasama yang baik diantara sesama karyawan maupun dengan atasan, tidak ada yang membolos, tidak ada yang membuat masalah, selalu datang tepat waktu karena karyawan sangat menikmati dari setiap pekerjaan yang karyawan lakukan, dengan adanya kesejahteraan akan dapat meningkatkan produktifitas dari kampus itu sendiri.

Sebaliknya, jika kesejahteraan dari karyawan tidak ada atau karyawan tidak merasa sejahtera maka akan dapat mempengaruhi kualitas kehidupan sosial ekonomi, religiusitas, kesehatan dan kualitas kerja karyawan (Larson, 1978).
Banyak hal yang menyebakan karyawan tidak merasa bahagia atau sejahtera dalam bekerja mulai dari rendahnya gaji yang didapatkan, atauran yang sangat ketat, kurangnya keamanan, tidak adanya cuti, kurangnya perhatian, dukungan dan adanya diskriminatif (De Jonge, Bosma, Peter, \& Siegrist, 2000; Kaukiainen, Salmivalli, Björkqvist, Österman, Lahtinen, Kostamo, \& Lagerspetz, 2001) sehingga akan berdampak terhadap keberadaan dari kampus itu sendiri.

Salah satu dari berbagai faktor yang membuat seseorang merasa bahagia atau sejahtera dalam pekerjaan adalah religiusitas. Religiusitas merupakan bagaimana seseorang memahami, meyakini, mengevaluasi, melakukan ritual dari agama yang diyakini dan mengimplementasikan ajaran dari agama tersebut dalam kehidupan. Bagi individu yang memiliki religiusitas yang baik maka akan memaknai atau mengerjakan segala pekerjaan dengan baik, ia akan meyakini segala perbuatan dan tingkah lakunya akan memiliki nilai ibadah di sisituhan 
(Ellison, 1991). Berdasarkan penelitian

Elçi, Sener, \& Alpkan (2011) menyatakan berpikir positif, mengerjakan pekerjaan dengan sungguh-sungguh maka dapat berdampak pada kinerja dan religiusitas karyawan. Individu yang seperti ini akan cenderung merasa bahagia dan merasa puas dengan kehidupannya karena ia mengerjakan dan menjalani segala kegiatan tanpa ada beban yang ia rasakan. Setiap individu berbeda dalam menterjemahkan sebuah kesejahteraan yang dirasakan, tergantung pada mengalaman, lingkungan sosialnya. Selain dari religiusitas beberapa peneliti lain juga menemukan bahwa, kepribadian juga berpengaruh terhadap kesejahteraan karyawan (Steel, Schmidt, \& Shultz, 2008).

Keunikan atau karakteristik dari kepribadian setiap individu itu berbedabeda antara individu yang satu dengan individu yang lain seprti mudah bergaul, aktif, lemah lembut, teratur dalam bekerja, mudah cemas, mudah emosi dan imajinatif. Adapun kepribadian dalam penelitian ini adalah kepribadian berdasarkan big five personality, teori ini didasarkan pada lima sifat dasar dari kepribadian (Pervin, Cervone, \& John, 2005), teori ini dapat menggambarkan sifat atau karakteristik dari individu secara keseluruhan tidak terkecuali kesejahteraan atau kebahagiaan yang dirasakan oleh seseorang.

Big five Personality atau dalam bahasa Indonesia lima besar sifat dari dimensi kepribadian yaitu extraversion berkaitan dengan sifat enerjik, Mudah bergaul, agreeableness atau lemah lembut, conscientiousness dengan kata lain berpikir sebelum bertindak dan teratur, neuroticism sering disebut dengan emosi negatif atau sifat pencemas, dan openness to new experience atau mempunyai daya imajinasi yang tinggi (Costa \& McCrae, 1992; John \& Srivastava 1999).
Ciri-ciri kepribadian tertentu berhubungan dengan berbagai jenis kesejahteraan. Misalnya, ekstroversi berhubungan dengan emosi positif, sedangkan neurotisme lebih berkaitan dengan perasaan negatif. Meskipun kepribadian berkorelasi penting dengan kesejahteraan subjektif, situasi dan keadaan hidup bisa dalam beberapa kasus memiliki pengaruh yang cukup juga. Selanjutnya, kepribadian bisa beberapa derajat berubah dari waktu ke waktu, dan dengan demikian tingkat kesejahteraan subjektif dapat berubah pula (Richard, E., \& Diener, 2009).

Berdasarkan uraian tersebut tujuan yang ingin dicapai dari penelitian ini untuk melihat bagaimana hubungan big five Personality dengan religiusitas serta subjektif well-being yang dirasakan oleh karyawan.

Subjektif Well-being merupakan sebuah evaluasi afektif dan kognitif individu terhadap kehidupan yang berkaitan dengan kebahagiaan, kesehatan, kedamaian, suasana hati terpenuhinya kebutuhan dan kepuasan terhadap kehidupan (Diener, Oishi, \& Lucas 2003). Unsur kognitif lebih kepada pemikiran seseorang tentang pencapaian dan kepuasan hidupnya secara menyeluruh maupun daerah kusus mengenai pekerjaan dan hubugan dengan orang terdekat. Sedangkan elemen afektif mengacu pada keadaan emosi, suasana hati dan perasaan yang dialami.

Berdasarkan hasil penelitian Rath, \& Harter (2010) mengungkapkan ada lima unsur penting untuk kesejahteraan yaitu: pertama kesejahteraan karir, dimana seseorang menghabiskan sebagian besar waktu disiang hari untuk bekerja. Kedua kesejahteraan sosial dimana hal ini mewakili interaksi, hubungan dan pengalaman cinta seseorang. Ketiga kesejahteraan keuangan ini merupakan seberapa baik seseorang mengelola 
situasi keuangannya. Keempat kesejahteraan fisik dimana kemampuan seseorang untuk memiliki kesehatan yang baik dan enerjik. Dan yang kelima kesejahteraan komunitas hal ini merupakan peran dan partisipasi dalam komunitas atau lingkungan dimana individu itu tinggal.

Religiusitas merupakan seberapa sering individu melaksanakan perintah agama, ciri khas individu dalam melaksanakan perintah agama, pentingnya agama bagi individu dan penghayatan individu terhadap agamanya (Huber \& Huber, 2012). Sedangkan menurut Ancok (2001) Religiusitas merupakan keberagamaan yang berarti meliputi berbagai macam sisi atau dimensi yang bukan hanya terjadi ketika seseorang melakukan perilaku ritual (beribadah), tapi juga ketika melakukan aktivitas lain yang didorong oleh kekuatan supranatural.

Menurut (Huber \& Huber, 2012) ada 5 dimensi religiusitas yaitu sebagai berikut :

a. Intelectual dimension dimensi ini menggambarkan mengenai minat, gaya pemikiran, interpretasi, dan sebagai ilmu pengetahuan. Indikator umum dimensi intelektual adalah frekuensi berpikir tentang isu-isu agama. Hal ini menunjukkan seberapa sering pengetahuan agama yang didapat melalui peroses berpikir, yang mengarah pada inti dari dimensi intelektual.

b. Ideology Dimension dimensi idiologi mengacu pada harapan sosial bahwa umat beragama memiliki keyakinan mengenai keberadaan dan esensi dari hubungan antara Tuhan dan UmatNya. Dalam konstruksi keagamaan, dimensi ini merepresentasikan kepercayaan, keyakinan yang tidak diragukan lagi, dan pola-pola yang masuk akal. c. Public Practice Dimension, dimensi public Practice mengacu pada harapan sosial bahwa umat beragama memiliki komunitas agama yang diwujudkan dalam partisipasi publik dalam ritual keagamaan dan kegiatan kumunal. Dalam konstruksi keagamaan seseorang, dimensi ini merepresentasikan pola tindakan dan rasa memiliki dengan sesama umat beragama, karena tuhan.

d. Private Practice Dimension, mengacu pada harapan sosial bahwa umat beragama mengabdikan diri untuk kegiatan agama secara individual atau peribadi. Dalam konstruksi keagamaan seseorang, dimensi ini merepresentasikan pola tingkah laku dan gaya atau cara seseorang dalam usahanya mendekatkan diri kepada tuhan.

e. Religious Experience Dimension, mengacu pada harapan sosial bahwa umat beragama memiliki semacam kontak langsung dengan realitas, serta mempengaruhi karyawan secara emosional.

Big Five adalah taksonomi dari kepribadian yang disusun berdasarkan pendekatan lexical, yaitu mengelompokkan kata-kata atau bahasa yang digunakan di dalam kehidupan sehari-hari, untuk menggambarkan ciriciri individu yang membeda-kannya dengan individu lain (Ramdhani, 2012). Berdasarkan hasil penelitian Costa \& McCrae (1992) kelima faktor tersebut mencakup seluruh aspek dari kepribadian yang didasarkan pada empat bukti pemikiran yaitu: pertama berdasarkan studi longitudinal menunjukkan bawa kelima faktor tersebut bertahan lama dalam pola perilaku. Kedua kelima faktor berhubungan dengan sifat yang ada dalam kepribadian setiap individu. Ketiga faktor-faktor yang ditemukan baik pada usia, jenis kelamin, ras, dan 
kelompok bahasa dan budaya yang berbeda cenderung hampir sama. Keempat semua faktor memiliki dasar biologis.

Adapun big five Personality tersebut menurut (Costa \& McCrae, 1992; John \& Srivastava 1999) yaitu extraversion berkaitan dengan sifat enerjik, Mudah bergaul, agreeableness atau lemah lembut, conscientiousness dengan kata lain berpikir sebelum bertindak dan teratur, neuroticism sering disebut dengan emosi negatif atau sifat pencemas, dan openness to new experience atau mempunyai daya imajinasi yang tinggi.

\section{METODE}

Desain penelitian ini menggunakan ex post facto. Ex post facto diartikan fakta yang sudah ada. ex post facto bertujuan untuk menggambarkan penelitian di mana kelompok terbentuk berdasarkan beberapa perbedaan sesuai fakta yang ada, bukan berdasarkan manifulasi seperti dalam model penelitian eksperimen (Cozby, 2012). Ex post facto bertujuan menemukan penyebab yang memungkinkan berubahnya perilaku, gejala atau fenomena yang disebabkan oleh suatu perilaku, gejala atau fenomena yang disebabkan oleh suatu peristiwa, atau hal-hal yang menyebabkan perubahan pada variabel bebas secara keseluruhan sudah terjadi (Simon \& Goes, 2013).

Subjek dalam penelitian ini adalah Karyawan Universitas Muhammadiyah Malang (UMM) yang berjumlah 55 orang. Dalam penelitian ini yang menjadi alat pengumpulan data adalah kuesioner. Kuesioner yang digunakan adalah kuesioner yang telah teruji validitas dan reliabilitasnya.

Penelitian ini menggunakan instrumen untuk mengukur variabelvariabel yang diteliti, berikut ini penjelasan untuk masing-masing instrument; Instrument yang digunakan untuk mengukur Big Five Personalty menggunakan The Big Five Inventory (BFI) yang dikembangkan oleh (John \& Srivastava, 1999) sejumlah 44 item. Skala yang digunakan adalah skala likert dari nilai 1 sangat tidak setuju sampai dengan 5 sangat setuju. Contoh item: "Suka penasaran dengan banyak hal yang berbeda"

Instrument yang digunakan untuk mengukur religiusitas menggunakan Religious Orientation Scale Revised (ROS-R) pertama sekali dikembangkan oleh Gordon Allport dan J. Michael Ross (1967), lalu direvisi oleh (Darvyri, et al, 2014) sejumlah 14 item. Skala yang digunakan adalah skala likert dari nilai 1 sangat tidak setuju sampai dengan 5 sangat setuju. Contoh item "Saya suka membaca (buku, majalah, dsb) tentang keagamaan"

Instrument yang digunakan untuk mengukur Subjective Well-being menggunakan Satisfaction with Life Scale yang dikembangkan oleh (Diener, Emmons, Larsen, \& Griffin, 1985) Sejumlah 5 Item. Skala yang digunakan adalah skala likert dari nilai 1 sangat tidak puas sampai dengan 7 sangat puas. Contoh item: "Jalan kehidupan saya paling mendekaati ideal"

Teknik analisis data yang digunakan dalam penelitian ini adalah korelasi Spearman untuk menganalisis hubungan antara big five Personality dan religiusitas terhadap kesejahteraan subjektif karyawan UMM. Teknik analisis ini sekaligus akan menunjukkan hubungan antara big five Personality dan religiusitas terhadap kesejahteraann subjektif karyawan pada universitas muhammadiyah malang.

\section{HASIL}


Tabel Hasil analisis korelasi Spearman Rho menunjukkan sebagai berikut :

Tabel 1. Hasil analisis korelasi

\begin{tabular}{|c|c|c|c|}
\hline \multicolumn{4}{|c|}{ Correlations } \\
\hline \multirow{19}{*}{ Spearman's rho } & & & Well-Being \\
\hline & Extraversion & Correlation Coefficient & $.269^{*}$ \\
\hline & & Sig. (2-tailed) & .047 \\
\hline & & $\mathrm{N}$ & 55 \\
\hline & Agreableness & Correlation Coefficient & .150 \\
\hline & & Sig. (2-tailed) & .274 \\
\hline & & $\mathrm{N}$ & 55 \\
\hline & Conscientiousness & Correlation Coefficient & .225 \\
\hline & & Sig. (2-tailed) & .098 \\
\hline & & $\mathrm{N}$ & 55 \\
\hline & Neuroticism & Correlation Coefficient & .252 \\
\hline & & Sig. (2-tailed) & .064 \\
\hline & & $\mathrm{N}$ & 55 \\
\hline & Openness & Correlation Coefficient & $.301^{*}$ \\
\hline & & Sig. (2-tailed) & .026 \\
\hline & & $\mathrm{N}$ & 55 \\
\hline & Religiusitas & Correlation Coefficient & $.351^{*}$ \\
\hline & & Sig. (2-tailed) & .009 \\
\hline & & $\mathrm{N}$ & 55 \\
\hline
\end{tabular}

Sebelum menguji analisis korelasi untuk melihat adanya hubungan antara variabel bebas dengan variabel terikat, peneliti terlebih dahulu melakukan uji asumsi syarat yaitu uji normalitas dan uji linieritas. Uji normalitas yang dilakukan menunjukkan bahwa data yang tersebar tidak berdistribusi normal karena nilai $\mathrm{p}<0,05$. Setelah melakukan uji normalitas, peneliti melakukan uji asumsi syarat yang kedua yaitu uji linieritas untuk melihat adanya hubungan yang linier diantara ketiga variabel. Hasil uji linieritas menunjukkan bahwa hubungan big five dengan well-being memiliki hubungan yang linier karena nilai $\mathrm{p}<0,05$, sedangkan Religiusitas dengan wellbeing tidak memiliki hubungan yang linier karena nilai $\mathrm{p}<0,05$.
Karena uji asumsi syarat yang dilakukan tidak terpenuhi, maka peneliti tidak bisa menggunakan uji analisis statistik parametrik korelasi product moment, sehingga peneliti menggunakan uji statistik non parametrik yaitu korelasi Spearman. Hasil analisis menunjukkan bahwa extraversion dan well-being memiliki hubungan yang signifikan dengan nilai p 0,047 $<0,05$ dengan nilai koefisien korelasi 0,269. agreableness dan well-being tidak memiliki hubungan yang signifikan dengan nilai $\mathrm{p} 0,274>0,05$ dengan nilai koefisien korelasi 0,150. conscientiousness dan well-being tidak memiliki hubungan yang signifikan dengan nilai p 0,098 >0,05 dengan nilai koefisien korelasi 0,225. Neuroticism dan well-being tidak memiliki hubungan 
yang signifikan dengan nilai $\mathrm{p} 0,064>$ 0,05 dengan nilai koefisien korelasi 0,252 , namun openness dan well-being memiliki hubungan yang signifikan karena nilai p 0,026 $<0,05$ dengan nilai koefisien korelasi 0,301. Sedangkan Religiusitas dan well-being memiliki hubungan yang sangat signifikan karena nilai p $0,009<0,05$ dengan nilai koefisien korelasi 0,351.

\section{DISKUSI}

Tujuan dari penelitian ini adalah untuk melihat hubungan antara big five personalty dan religiusitas dengan subjective well-being karyawan universitas muhammadiyah malang. Maka dapat dijelaskan hasil penelitian ini menunjukkan bahwa exstraversion dan openness mempunyai hubugan dengan well-being, sedangkan agreeableness, conscientiousness dan neuroticism tidak mempunyai hubugan dengan well-being. Hal ini menunjukkan bahwa semakin individu mengarah pada exstraversion, dan openness maka tingkat well-being juga semakin baik. Hasil penelitian ini sejalan dengan hasil penelitian yang dilakukan oleh Steel, Schmidt, \& Shultz (2008) mengatakan bahwa kepribadian secara substansial pempunyai hubugan dengan kesejahteraan subjektif kususnya pada exstraversion. Individu yang exstraversion, openness tinggi cenderung merasakan kebahagiaan hal Ini disebabkan karena exstraversion dan openness mampu menunjukkan tingkat kesenangan akan hubungan, terhadap hal yang baru serta mempunyai kebutuhan untuk didukung dalam aktifitas.

Sedangkan penelitian (Soto, 2015) menunjukkan bahwa individu yang awalnya extraverted lalu menyenangkan, teliti dalam segala hal, dan emosi yang stabil akan meningkat pada kesejahteraan yang dirasakan. Sejalan dengan itu hasil penelitian Zhai,
Willis, O'Shea, Zhai, \& Yang (2013) menunjukkan bahwa antara extraversion dan subjective well-being sebagian dimediasi oleh kepuasan kerja hal ini menyiratkan bahwa efek dari Big Five pada subjective well-being secara langsung dari kepuasan kerja. Apabila individu merasa puas dengan pekerjaan yang dilakukan maka kebahagian akan muncul dengan sendirinya. Nampaknya dari kelima dimensi yang ada pada big five personality hanya extraversion lah yang paling dapat mengukur kesejahteraan subjektif karyawan, hal ini dapat dilihat dari keseluruhan hasil penelitian diatas.

Hasil analisis yang dilakukan pada religiusitas juga memiliki hubungan yang signifikan dengan subjective well-being, hal ini berindikasi bahwa semakin tinggi tingkatan religiusitas yang dirasakan individu maka semakin tinggi juga kesejahteraan yang dirasakan. Hal ini sejalan dengan hasil penelitian Ellison (1991) menunjukkan bahwa ada pengaruh positif antara keyakinan beragama terhadap kesejahteraan yaitu bersifat langsung dan substansial: individu dengan keyakinan agama yang kuat melaporkan tingkat kepuasan hidup, kebahagiaan pribadi yang lebih besar, lebih sedikit masalah sosial yang dialami dan tidak ada peristiwa kehidupan traumatis.

Sejalan dengan itu Witter, Stock, Okun, \& Haring (1985) menemukan bahwa agama secara signifikan, berhubungan positif dengan kesejahteraan subjektif. Hubungan antara agama dan kesejahteraan subjektif cukup kuat untuk kegiatan keagamaan.

\section{SIMPULAN}

Berdasarkan hasil penelitian dengan menggunakan uji statistik non parametrik yaitu korelasi Spearman, 
didapatkan hasil bahwa terdapat hubugan signifikan antara exstraversion, openness dan religiusitas dengan subjective well-being, sedangkan agreeableness, conscientiousness dan neuroticism tidak mempunyai hubugan dengan well-being.

Berdasarkan penelitian yang telah dilakukan, maka peneliti menyarankan agar pimpinan kampus lebih meningkatkan lagi kesejahteraan karyawan dari sisi gaji, bonus, kenyamanan ditempat kerja sehingga dapat meningkatkan kesejahteraan dan kebahagian yang dirasakan oleh karyawan. Bagi peneliti yang ingin meneliti kesejahteraan karyawan diharapkan menambah subjek yang diteliti serta menggunakan variabel yang dapat mempengaruhi kperibadian, sehingga mendapatkan hasil yang lebih memuaskan atau mungkin dapat melihat dari sisi yang lain seperti gaji yang didapatkan karyawan.

\section{DAFTAR PUSTAKA}

Allport, G. W., \& Ross, J. M. (1967). Personal religious orientation and prejudice. Journal of personality and social psychology, 5(4), 432.

Ancok, D., Suroso, F. N. (2001). Psikologi Islami: Pustaka Pelajar.

Costa, P. T., \& McCrae, R. R. (1992). Four Ways Five Factors are Basic. Personality and Individual Differences, 13(6), 653-665.

Darvyri, P., Galanakis, M., Avgoustidis, A. G., Pateraki, N., Vasdekis, S., \& Darviri, C. (2014). The Revised Intrinsic/Extrinsic Religious Orientation Scale in a Sample of Attica's Inhabitants. Psychology, 5(13), 1557.
De Jonge, J., Bosma, H., Peter, R., \& Siegrist, J. (2000). Job Strain, Effort-Reward Imbalance and Employee Well-Being: a LargeScale Cross-Sectional Study. Social Science \& Medicine, 50(9), 1317-1327.

Diener, E., Emmons, R. A., Larsen, R. J., \& Griffin, S. (1985). The Satisfaction with Life Scale. Journal of Personality Assessment, 49, 71-75.

Diener, E., Oishi, S., \& Lucas, R. E. (2003). Personality, Culture, and Subjective Well-Being: Emotional and cognitive evaluations of life. Annual review of psychology, 54(1), 403-425.

Elçi, M., Sener, İ., \& Alpkan, L. (2011). The Impact of Morality and Religiosity of Employees on Their Hardworking Behavior. Procedia-Social and Behavioral Sciences, 24, 13671377.

Ellison, C. G. (1991). Religious Involvement and Subjective WellBeing. Journal of Health and Social Behavior, 80-99.

Huber, S., \& Huber, O. W. (2012). The Centrality of Religiosity Scale (CRS). Religions, 3(3), 710-724.

John, O. P., \& Srivastava, S. (1999). The Big Five Trait Taxonomy: History, Measurement, and Theoretical Perspectives. Handbook of Personality: Theory and Research, 2(1999), 102-138.

Kaukiainen, A., Salmivalli, C., Björkqvist, K., Österman, K., Lahtinen, A., Kostamo, A., \& Lagerspetz, K. (2001). Overt and 
Covert Aggression in Work Settings in Relation to the Subjective Well- Being of Employees. Aggressive Behavior, 27(5), 360-371.

Larson, R. (1978). Thirty years of research on the subjective wellbeing of older Americans. Journal of Gerontology, 33(1), 109-125.

Pervin, L. A., Cervone, D., \& John, O. P. (2005). Persönlichkeitstheorien. Stuttgart: UTB.

Ramdhani, N. (2012). Adaptasi Bahasa dan Budaya dari Skala Kepribadian Big Five. Jurnal Psikologi, 39(2), 189-205.

Rath, T., \& Harter, J. (2010). The Economics of Wellbeing. Gallup Press. Retrieved January, 23, 2015.

Richard, E., \& Diener, E. (2009). Personality and Subjective WellBeing. In the Science of WellBeing (pp. 75-102). Springer Netherlands.

Robbins, S. P., \& Judge, A. T. (2011). Organizational Behavioral. New Jersey: Pearson.

Sirgy, M. J. (2016). Towards a New Concept of Residential WellBeing Based on Bottom-Up Spillover and Need Hierarchy Theories. In a Life Devoted to Quality of Life (pp. 131-150). Springer International Publishing.

Soto, C. J. (2015). is Happiness Good For Your Personality? Concurrent and Prospective Relations of the Big Five With Subjective
Well- Being. Journal of Personality, 83(1), 45-55.

Steel, P., Schmidt, J., \& Shultz, J. (2008). Refining the Relationship Between Personality and Subjective Well-Being. Psychological Bulletin, 134(1), 138.

Witter, R. A., Stock, W. A., Okun, M. A., \& Haring, M. J. (1985). Religion and Subjective WellBeing in Adulthood: a Quantitative Synthesis. Review of Religious Research, 332-342.

Zhai, Q., Willis, M., O'Shea, B., Zhai, Y., \& Yang, Y. (2013). Big Five Personality Traits, Job Satisfaction and Subjective WellBeing in China. International Journal of Psychology, 48(6), 1099-1108. 